\title{
Disturbance and rehabilitation of lakeside Phragmites reeds following an extreme flood in Lake Constance (Germany)
}

\author{
Wolfgang Ostendorp ${ }^{1}$, Michael Dienst ${ }^{2}$ \& Klaus Schmieder ${ }^{2}$ \\ Limnologisches Institut, Universität Konstanz, D-78457 Konstanz, Germany \\ E-mail: wolfgang.ostendorp@uni-konstanz.de \\ ${ }^{2}$ Institut für Landschafts- und Pflanzenökologie, Universität Hohenheim, D-70593 Stuttgart, Germany
}

Key words: Phragmites australis, disturbance ecology, flooding tolerance, littoral vegetation, reed die-back, stand structure

\begin{abstract}
After an extreme flood in Lake Constance in 1999 the Phragmites australis belt showed a severe decline in area and vitality. A three year monitoring project was installed in 2000 to document the die-back and rehabilitation process immediately afterwards, to identify the co-factors of the damage, and to find out significant stressors that may impede the recovery of the reeds. The monitoring is based on CIR aerial photo interpretation, quantitative GIS analyses and field investigations on shoot density, stand structure and biomass production in 50 monitoring plots, grouped in five degrees of damage. In result we found that c. $0.306 \mathrm{~km}^{2}$ of aquatic reed bed area died back at Lake Constance-Untersee (i.e. 23\% of the former area in 1998). Among the stands which had survived the severely damaged stands were mainly composed of secondary shoots, whereas primary and insect infested shoots dominated in less damaged stands. The development from 2000 to 2001 was characterized by an overall decrease in shoot density, a change in the composition of the shoot population in favour of primary shoots, and in a recovery in culm stature. All variables depended on the degree of initial damage by the extreme flood. A conceptual model is proposed to assess the future development of Lake Constance reeds.
\end{abstract}

\section{Introduction}

The common reed Phragmites australis (Cav.) Trin. ex Steud. (Poaceae) plays an important role in the littoral zone of many lakes in the northern hemisphere (Rodewald-Rudescu, 1974). The reed belts protect the shoreline from bank erosion, retain nutrients from non-point sources and thereby act as buffer zones between arable land and the open water, serve as a food resource for arthropods, birds and mammals, and form a typical habitat structure for many endangered species which are adapted to them (Ostendorp, 1993).

A 'die-back' of reed belts has been observed in many European lakes for about five decades (Ostendorp, 1989; Van der Putten, 1997; Brix, 1999) so that these ecological functions are impaired. The main factors which had been made responsible for the decline comprise harmful human impacts like direct destruction, land fills in the shore zone, embankments and construction of piers, recreational use, introduc- tion of alien grazer species like muskrat and coypus, eutrophication and waste water dumping, and ground water and lake level manipulation. Much less is known about the dynamics of the reed belt front under a fairly natural disturbance regime of episodic extreme hydrological events (high floods and low water periods), since the water level of most of the central European lakes has been artificially regulated for half a century or more.

Lake Constance is the only great lake in the northern alpine forelands which exhibits an essentially natural water level regime with mean yearly fluctuations of $1.43 \mathrm{~m}$ between low water in January/February and high water in June/July. Extreme floods in the last 50 years occurred in 1965, 1987, and 1999, extended low water periods in summer accumulated in the last fifteen years (1989, 1992, 1996 and 1998). In particular, the high water levels in 1965-67 led to a loss of c. 32 hectares of aquatic reed belt in Lake Constance-Untersee, as was established many years 
after by aerial photo interpretation (Ostendorp, 1990). Hence, Lake Constance may serve as a model to investigate the disturbance ecology of Phragmites reeds in peri-alpine lakes, the limits of their flooding tolerance under field conditions, and the strategies of stand structure rehabilitation and space re-occupation.

\section{Study site}

Lake Constance is the largest and deepest lake in the northern alpine forelands. It is divided into the deep Obersee $\left(500 \mathrm{~km}^{2}, 254 \mathrm{~m}\right.$ maximum depth, $395.27 \mathrm{~m}$ a.s.l., mean water level 1951-2001), and the shallow Untersee ( $71.5 \mathrm{~km}^{2}, 46 \mathrm{~m}, 395.08 \mathrm{~m}$ a.s.l.). The basins are connected by the river Seerhein and underlie the same hydrological regime which depends mainly on the discharge of the Alpenrhein river. In June and July the water level reaches its maximum (396.44 m a.s.l., mean from 1951 to 2001 for the Obersee) due to ice and snow melting in the alpine regions and summer rainfalls in the forelands (Fig. 1). Then the water drops down gradually to the yearly minimum in January and February (394.46 $\mathrm{m}$ a.s.l.) when the precipitation is stored as snow and ice at higher altitudes.

About $85 \%$ of the Phragmites reeds (German territory only) grow at the shores of the Untersee, a eutrophic lake with extended gently sloped shores, only $15 \%$ are found in narrow fringes at the steeper sloped shores of the mesotrophic Obersee. More than 99\% of the aquatic reeds are formed by monospecific stands of Phragmites australis, covering a total of nearly $1.10 \mathrm{~km}^{2}$ in the 1990 s (German territory only). The young shoots of Phragmites australis start to grow in late April and early May at the expense of the carbohydrate and nutrient reserves which are stored in the extensive rhizome network. Hence, the vitality of the present shoot generation depends on the amount of photosynthetic assimilates accumulated by the previous years' shoot generation. The shoots continue their linear growth till mid July, and the stouter ones (i.e. 'primary shoots', PSH) flower in the second half of August and wither after the first night frosts in late October. Other shoots bear apical galls induced by parasitic arthropods (i.e. 'insect infested shoots', ISH) or their apex ends in a close-furled leaf similar to those of immature shoots (i.e. 'secondary shoots', $\mathrm{SSH}$ ). The bulk of the buds emerge in spring but some do not come out until July ('summer shoots', SUS); they die in late autumn in an immature state.

\section{Study design, methods}

The monitoring programme combines quantitative GIS evaluation of CIR (colour infra-red) aerial photos and field measurements along 50 monitoring plots.

The aerial photos were orientated and georeferenced using the photogrammetric plotter Planicomp P 33 (Zeiss, Oberkochen, Germany) with the Zeiss PCAP software. The reed front and the contours of reed areas of a particular damage degree were digitized with the CAD software MicroStation (Bentley Systems Inc., U.S.A.). The final data evaluation and presentation was done with ArcInfo/ArcView (ESRI, Kranzberg, Germany). The landside border of aquatic reed was defined to be at $395.5 \mathrm{~m}$ a.s.l. at Lake Constance-Untersee (395.7 m a.s.l., Obersee), corresponding to a mean annual submergence period of 3 months.

The monitoring plots were allocated to 10 groups along five degrees of flood damage (G1undamaged,...,G5 - extremely damaged) and two locations (LOC: A - front standing reeds, B-reeds c. 10 $-20 \mathrm{~m}$ behind the reed front), to give a $5 \times 2$ data matrix with 5 replicates in each cell. G refers to the initial degree of damage as it was assessed in August 2000 on the basis of aerial photo interpretation and field observation. The replicates in each cell were randomly selected along the shore of Lake Constance using the qualitative impression from the aerial photos from 22-07-2000 as an a priori background information (stratified random sampling). Field sampling and measurements were done in the second half of August 2000 and of August 2001. The variables discussed in this paper comprise shoot density $\mathrm{Z}\left[\# \mathrm{~m}^{-2}\right.$ ], the percent composition of the shoot population Z\% [\%] and culm biomass CBM [g d.wt.] of the primary shoots (PSH).

The development of the shoot density from 2000 to 2001 was calculated on the basis of the 'relative change in shoot density' $r Z$ with:

$$
\begin{array}{r}
\mathrm{rZ}[1]=\left(\mathrm{Z}_{2001}-\mathrm{Z}_{2000}\right) /\left(0.5 \times\left(\mathrm{Z}_{2001}\right.\right. \\
\left.\left.+\mathrm{Z}_{2000}\right)\right),-2 \leq \mathrm{rZ} \leq+2
\end{array}
$$

This definition of $\mathrm{rZ}$ makes reference to the fact that the biological meaning of a certain increase or decrease in (absolute) density depends on the initial density. The relative change in culm biomass was defined in a similar way as:

$$
\begin{aligned}
& \mathrm{rCBM}[1]=\left(\mathrm{CBM}_{2001}-\mathrm{CBM}_{2000}\right) /(0.5 \times \\
& \left.\left(\mathrm{CBM}_{2001}+\mathrm{CBM}_{2000}\right)\right),-2 \leq \mathrm{rCBM} \leq+2
\end{aligned}
$$



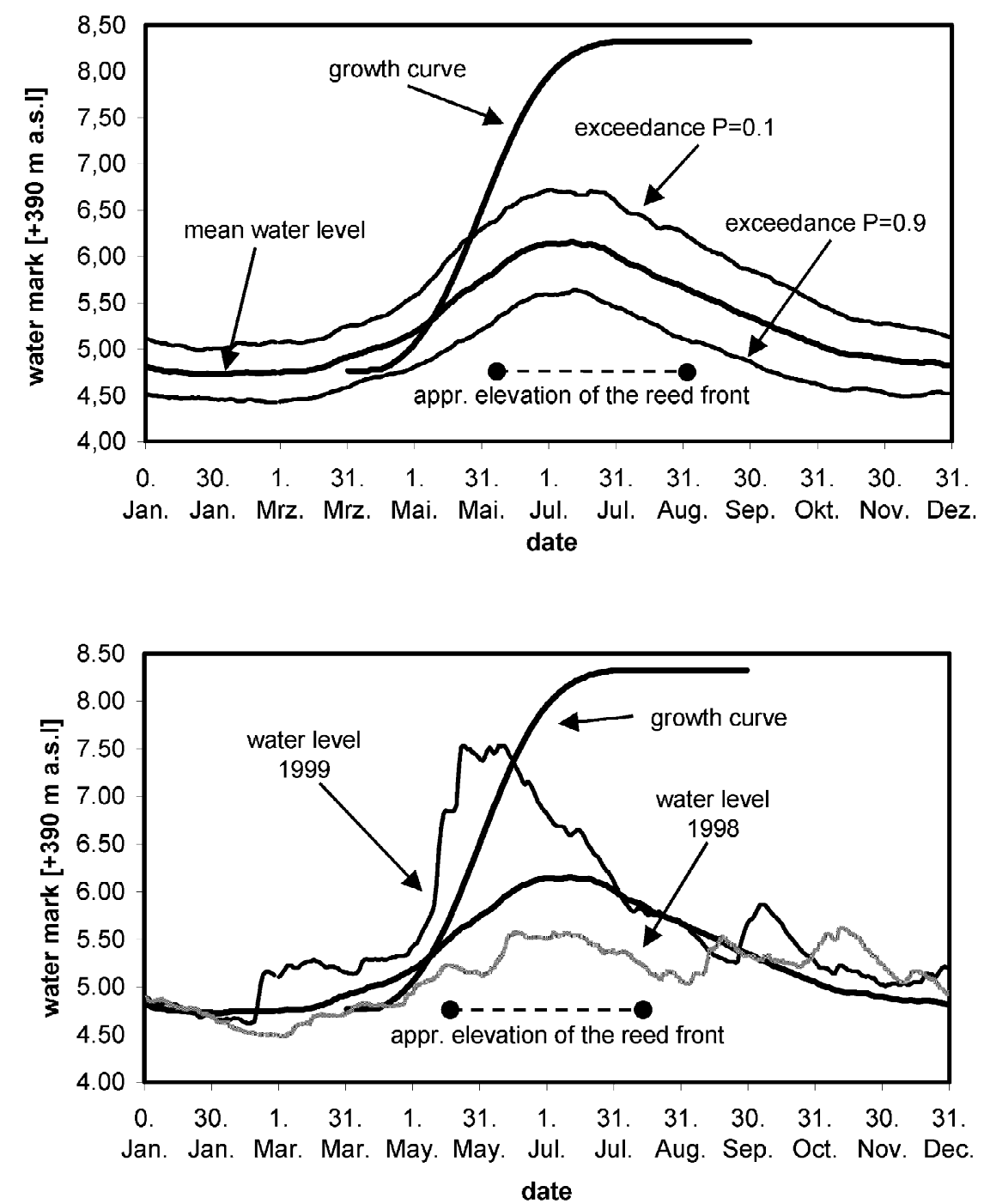

Figure 1. Hydrology of Lake Constance-Obersee and shoot growth of $P$. australis reeds: (a) annual course of the mean water level (daily records, water mark station at Constance), exceedence probablities $P=0.1$ (i.e. water level surpasses this mark in 1 out of 10 years), and $P=0.9$ (i.e. water level does not surpass this mark in 1 out of 10 years), shoot growth curve for an average primary shoot at the reed front (appr. elevation -0.5 m below mean water level) (b) extreme water levels in 1998 and 1999, the mean water level curve and the shoot growth curve are given for comparison.

Statistical evaluation was done with parametric twoway Anova with G (degree of damage) and LOC (location) as factors, or with non-parametric twoway Anova (method of Scheirer et al., 1976). See Schmieder et al. (2002) for a more detailed description of methods and measuring protocols.

\section{Results}

The extreme flood in 1999 brought the fourth highest water level that has been recorded at Lake Constance since the begin of continuous water mark records in 1817 due to heavy rainfalls in the catchment area and around from 11th to 14th and from 19th to 21st of May 1999. The flood came very early in the season, just in the first third of the growth period of Phragmites australis. (Fig. 1). Many shoots suffered from drowning, and stopped their growth. Those which penetrated the 


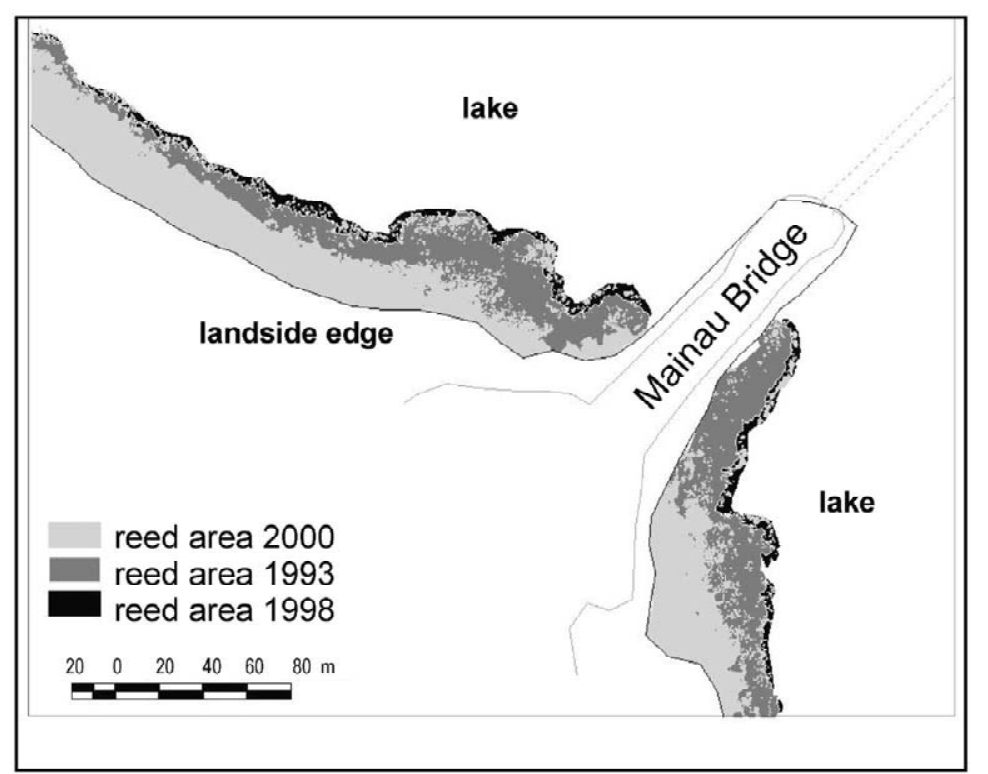

Figure 2. Flood-induced reed die-back in Lake Constance-Obersee (GIS map from aerial photos near the Mainau isle. The increase in area between 1993 and 1998 is shown in black, the reed beds which have survived till July 2000 are given in light grey (i.e. fail area where reeds died after 1999 is the sum of black and dark grey area).

water surface were damaged mechanically by waves and drifting matter during a heavy storm on 2 nd of June 1999.

The GIS evaluation of the aerial photos from May 1999 showed that in 1998 the total area of aquatic reed amounted to $1.352 \mathrm{~km}^{2}$ (shoreline in the State of Baden-Württemberg only). In July $20001.047 \mathrm{~km}^{2}$ were still alive, however in more or less bad condition (Fig. 2). This is a loss of $0.306 \mathrm{~km}^{2}$, i.e. $22.6 \%$ of the former area of aquatic reeds. A great longshore and cross-shore patchiness of more or less severely damaged reed spots was detected, indicating that additional factors have modified the flooding effect.

In August 2000, when the monitoring programme was performed for the first time, the shoot density in the monitoring plots differed significantly in respect to their initial degree of damage $\mathrm{G}(P<0.0001$ for the $G$ effect in the two-way Anova with G and LOC as factors). In the weakly damaged stands, G1 and G2, the density was about $25-40$ shoots per $\mathrm{m}^{2}$, which is quite normal compared with the range for Lake Constance reeds in the years before. In heavily damaged stands, G4 and G5, this value dropped down to c. 5 - 12 shoots per $\mathrm{m}^{2}$ (Fig. 3a). The mean density in the front standing reeds $(\mathrm{LOC}=\mathrm{A})$ was higher than in the more landside reeds $(P<0.05$ for the LOC effect; no significant $\mathrm{G}^{*} \mathrm{LOC}$ interactions). In 2001 a similar situation was observed $(P<0.0001$ for the $\mathrm{G}$ effect) but LOC was not significant (Fig. 3b). The development of the shoot density from 2000 to 2001 was calculated as the 'relative change in shoot density' $r Z$. The effect of $\mathrm{G}$ and $\mathrm{LOC}$ on $\mathrm{rZ}$ is shown in Figure 3c. Both factors were significant $(P<0.01$ for $\mathrm{G}, P<0.05$ for LOC, no significant $G^{*}$ LOC interactions). The relative change in shoot density was near zero for slightly and medium damage stands (G1 - G3) whereas it was significantly lower than zero in heavily damaged stands (G4 and G5). This indicates that even in the years after the flood the thinning at least of the severely damaged stands continues. The front standing reeds $(\mathrm{LOC}=\mathrm{A})$ exhibited a more negative development, and in the inner part of the reed belt $(\mathrm{LOC}=\mathrm{B})$ the shoot density trend was less negative or even positive.

The percent composition of the shoot population (Z\%) depended strongly on $\mathrm{G}(P<0.0001$ for PSH and SSH, $P<0.05$ for ISH in 2000) but not on LOC, the effect of which was not significant for all shoot classes (Fig. 4a). The share of primary shoots decreased from about $27-54 \%$ in slightly damaged stands (G1, G2) to near zero in extremely damaged stands (G5). In contrast, the percentage of secondary shoots increased from c. $19-29 \%$ in the G1 and G2 groups to $54-86 \%$ in G4 and G5. The percentage of insect infested shoots was highest in slightly and medium damaged stands. The SUS were of minor importance, reaching higher 


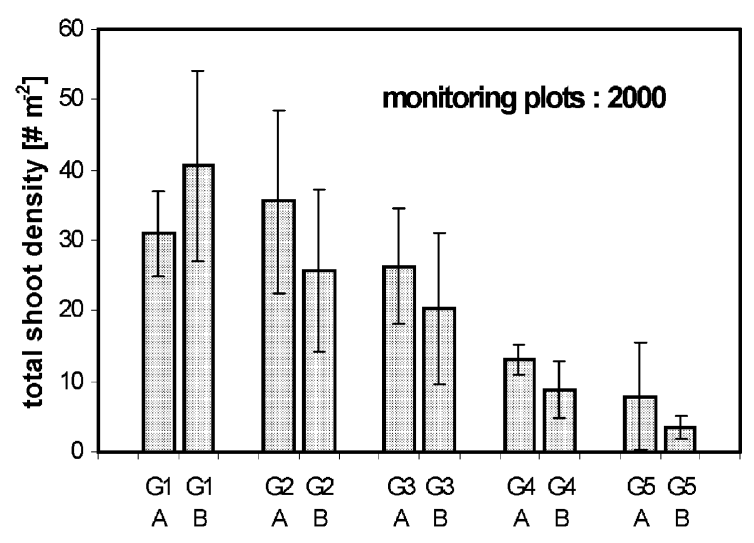

G-groups, LOC-groups
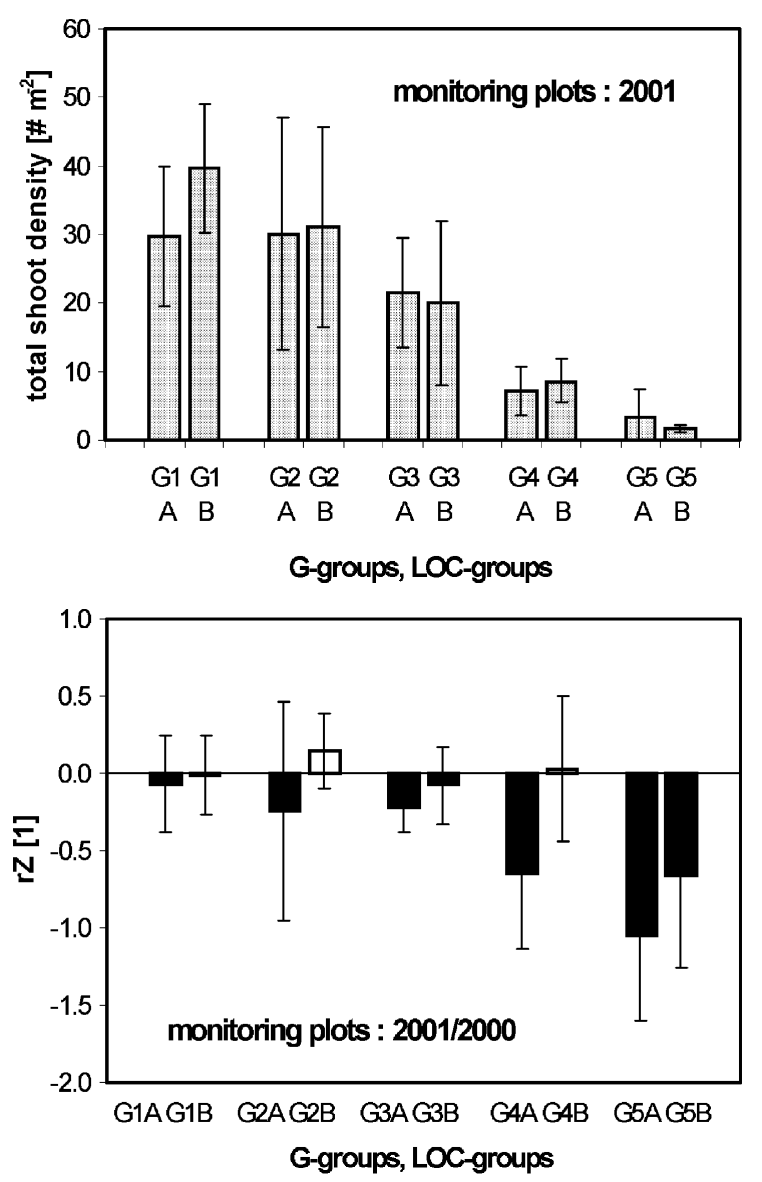

Figure 3. Total shoot density in reed stands classified as G1 to G5 (degree of damage) at the reed front (LOC A) and in the inner part of the aquatic reeds (LOC B), in August 2000 (a), in August 2001 (b), and the effect of G and LOC on the relative difference in shoot density (rZ) (c) (negative values shown as black columns), means \pm st.dev's, with $n=5$ monitoring plots in each group (see text for further explanations).
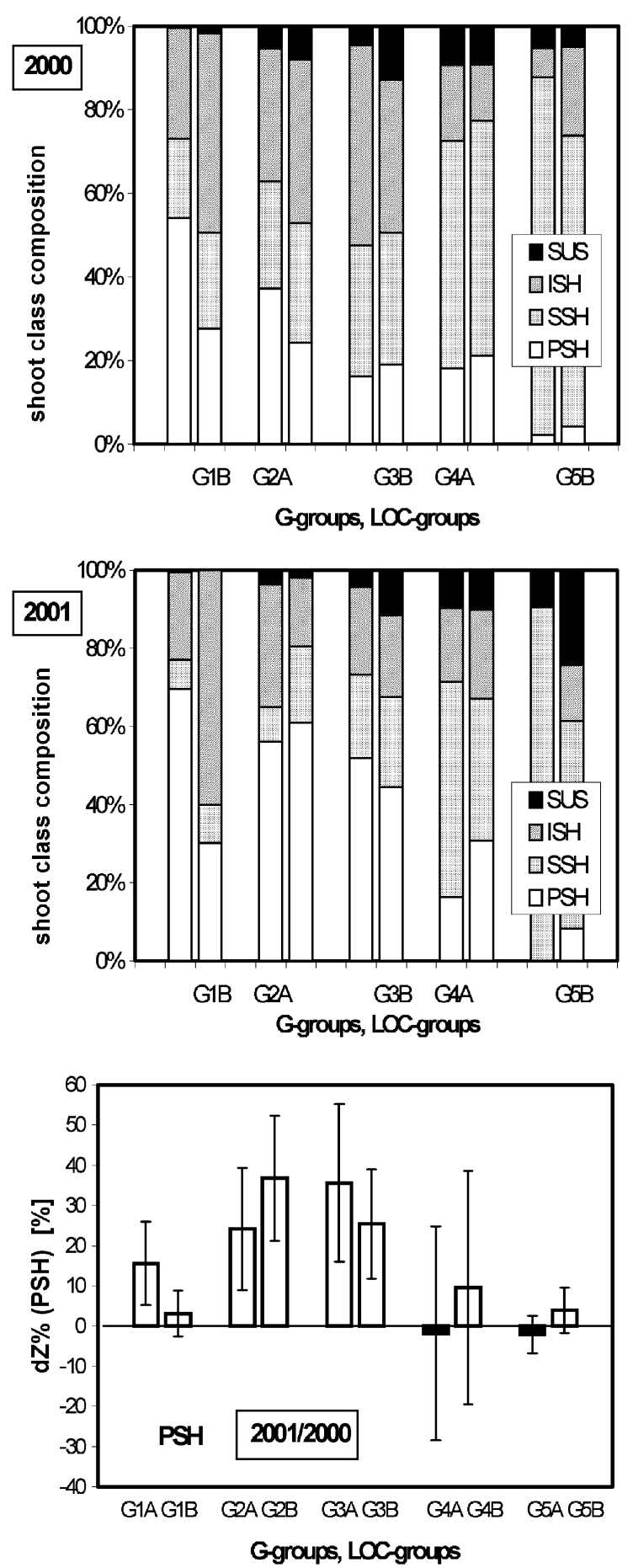

Figure 4. Effect of the degree of damage (G) and the location (LOC, $\mathrm{A}$ - reed front, $\mathrm{B}$-inner part of the aquatic reeds) on the composition of the shoot population in August 2000 (a), in August 2001 (b), and on the difference in primary shoot (PSH) percentage (dZ\%) (c) (negative values shown as black columns), means \pm st.dev's, with $n=4-5$ monitoring plots in each group (see text for further explanations). 
values only in heavily damaged monitoring plots. In 2001 essentially the same was observed, and again the $\mathrm{G}$ effect was highly significant $(P<0.001$ for all shoot classes except SUS), but LOC was not significant (Fig. 4b). Figure 4c shows the development of the percentage of $\mathrm{PSH}\left(\mathrm{dZ} \%_{P S H}\right)$ in the shoot population from 2000 to 2001. The increase in PSH percentage was greatest in the medium damaged stands (G2 and G3), and was near zero or negative in G4 and G5. This $\mathrm{G}$ effect was significant $(P<0.01)$. No significant LOC effect or $\mathrm{G}^{*}$ LOC interactions were observed. The mean percentage of SSH decreased in lower degrees of damage and remained more or less unchanged in higher damaged groups. This and all other shoot classes did not show any significant influence of $\mathrm{G}$ or LOC.

The mean culm biomass (CBM) decreased along with the increasing degree of damage $G$ in 2000 in all shoot classes except SUS (Fig. 5a). The mean biomass of the PSH, for instance, decreased from $42-49 \mathrm{~g}$ d.wt. (G1) to $19 \mathrm{~g}$ d.wt. in G5. The influence of $\mathrm{G}$ was significant only in the case of SSH $(P<0.01)$, and LOC had no significant effect on CBM in any shoot class. Nearly the same distribution was encountered in 2001 (Fig. 5b), where $\mathrm{G}$ had a significant effect on the CBM of all shoot classes $(\mathrm{P}<0.05)$ except SUS, but LOC had not. Figure $5 \mathrm{c}$ shows the relative change in culm biomass rCBM was always positive for PSH without any significant influence of G or LOC (Fig. 5c). There was, however, a strong tendency that the increase in $\mathrm{rCBM}$ was greater in the inner part of the reed belt (B) than in the frontstanding reeds (A). In $\mathrm{SSH}$ and ISH the mean $\mathrm{CCBM}$ was positive in minor and medium damaged monitoring plots and negative in extremely damaged stands. Again, the within-group variability was too great to give significant $\mathrm{G}$ or LOC effects.

\section{Discussion}

Lake Constance is the only great lake in the norther alpine foreland whose water level regime has not been manipulated by man so that this lake can be used to model the long term relation between (i) trends and extremes in water level, and (ii) stand structure and maximum depth penetration of fringing aquatic Phragmites reeds. Our approach is that the maximum depth penetration of the aquatic reeds should reach an equilibrium under constant conditions of yearly water level course and mechanical stress to the reed
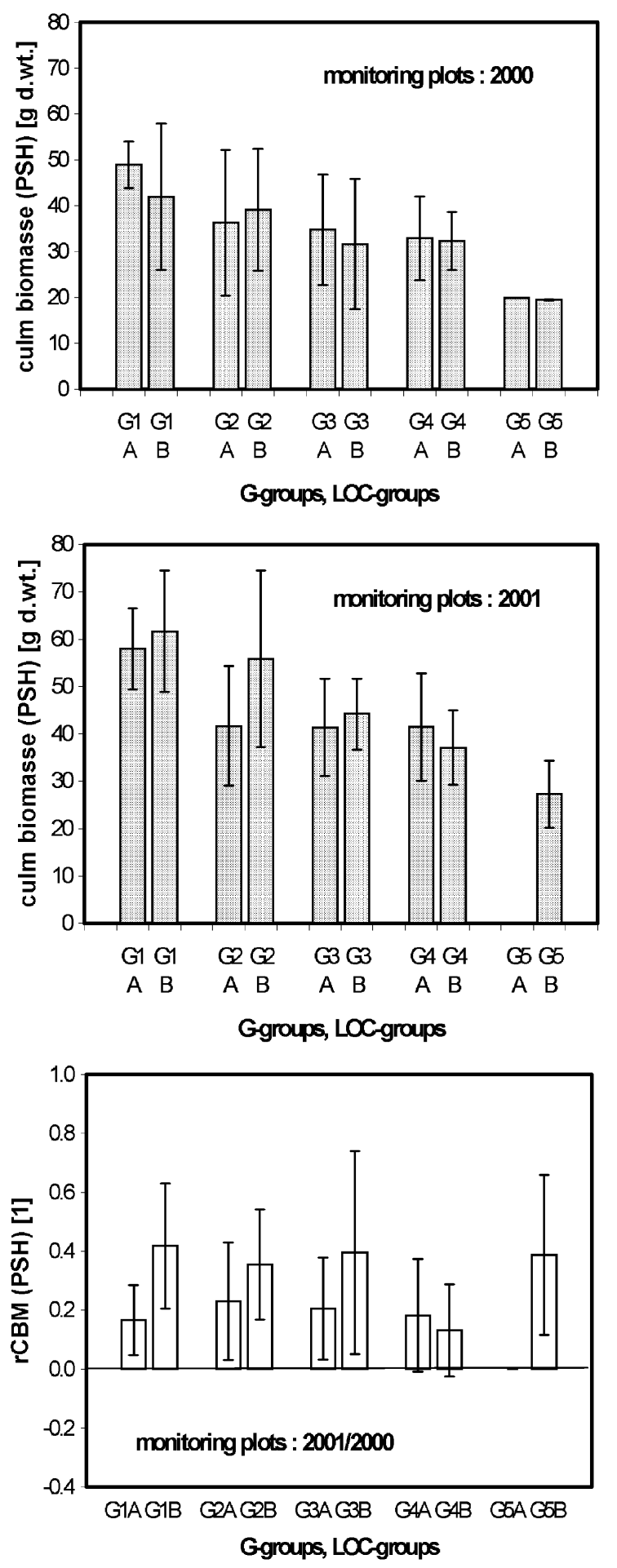

Figure 5. Effect of the degree of damage $(\mathrm{G})$ and the location (LOC, $\mathrm{A}$ - reed front, B -inner part of the aquatic reeds) on the culm biomass of primary shoots (PSH) in August 2000 (a), in August 2001 (b), and on the relative difference in culm biomass (rCBM) (c), means \pm st.dev's, with $n=3-5$ monitoring plots in each group (see text for further explanations). 


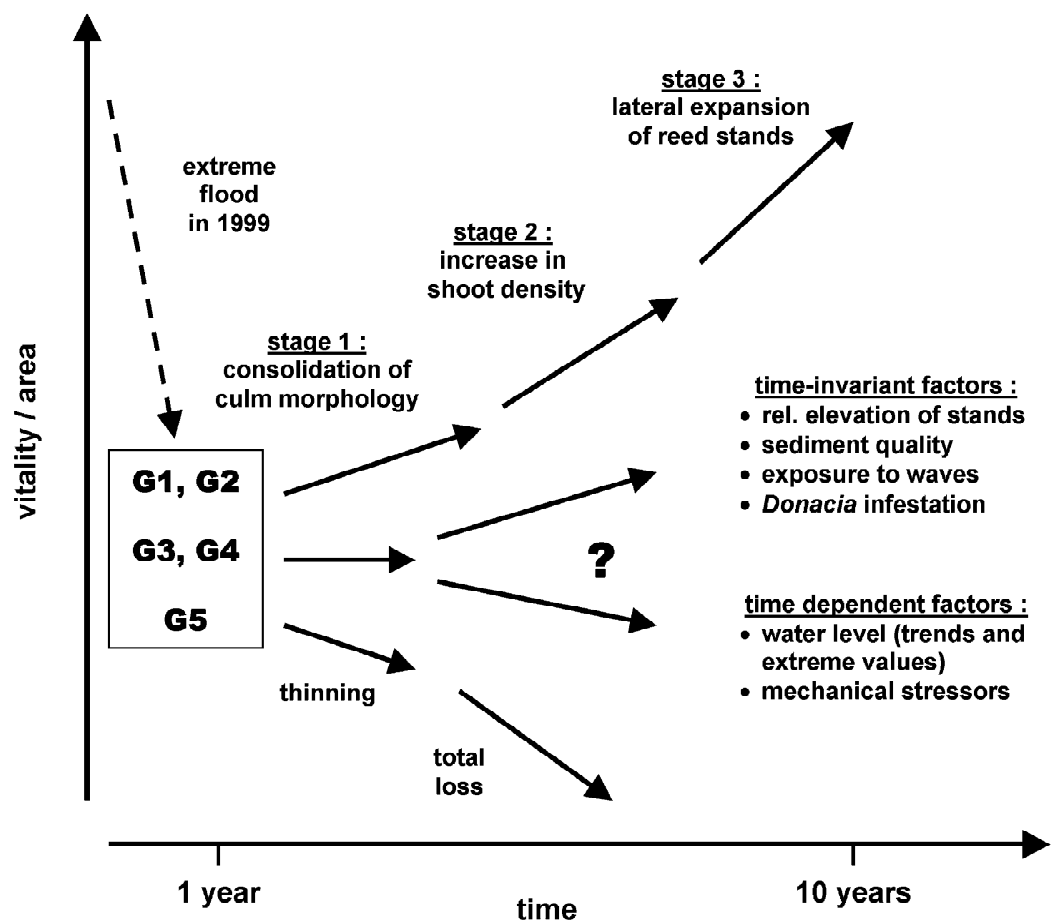

Figure 6. Conceptual model of disturbance, die-back and recovery of aquatic Phragmites reeds in Lake Constance, following the extreme flood in 1999 ( $\mathrm{G}$ - degree of damage; see Discussion section for details).

front (e.g. waves and washes by macrophyte debris). This hypothetical equilibrium line is never reached due to more or less frequent and intense disturbance events (cf. White \& Pickett, 1985; White \& Jentsch, 2001) which induce an episodic retreat of the reed front laterally as well as vertically towards a higher elevation. We use the extreme flood in 1965 whose consequences have been well documented post festum by aerial photos and reed front mapping programmes as an example of the long term reaction (Ostendorp, 1990), and the event of 1999 to investigate the fine structure of die-back and recovery of differently damaged Phragmites stands on a whole-lake basis. We can compare this with the extreme flood in 1987 which had only a slight effect on the reed front dynamics. As to the present state of data evaluation we propose the following descriptive model (Fig. 6).

The initial die-back process is very rapid and happens within a few weeks during and after the peak phase of the flood: the young shoots are flooded while rapidly growing at the expense of the carbohydrates storage of the rhizomes. They are isolated from subaerial oxygen supply, and the anaerobic metabolism which starts within a few days cannot meet the energy requirements for further growth (Brändle \& Crawford,
1987; Brändle, 1985). The shoots stop growing and die down after a while as do the rhizomes due to carbohydrate exhaustion (Brändle, 1983, 1985; Studer \& Brändle, 1984). This should be true for waterside (deeply flooded) stands but not for landside (slightly flooded) reeds. Indeed, we found by logistic regression that the probability of a reed stand being seriously damaged depends significantly on its elevation relative to the mean water level (Schmieder et al., 2002).

Besides the elevation there must exist other factors that control the pattern of differently damaged reeds (see Fig. 2). We have some indication that alternative oxygen sinks (e.g. sediment oxygen demand, parasitic larvae of the chrysomelid beetle Donacia sp.) are among these factors (Ostendorp, unpublished data). Additionally, the pre-condition of the stand may have played an important role, but this cannot be reconstructed with sufficient reliability. Following the mechanism described above, the most prominent response of the Phragmites reeds is a thinning in shoot density (see Fig. 3a) and a change in the shoot class composition (see Fig. 4a), whereas the culm biomass of the surviving shoots is effected to a minor degree (see Fig. 5a). This holds also for the aboveground standing crop and for the culm architecture (i.e. shoot 
height, number of leaves, etc.), respectively (data not shown here).

Since Phragmites australis is not able to re-occupy the die-back areas or the gaps in disintegrated stands by seedlings (Hürlimann, 1951; Rodewald-Rudescu, 1974; Conert, 1998), the recovery of stands and the lakeside progression is exclusively vegetative by short rhizome runners (phalanx strategy, Urbanska, 1992) or by long runners or stolons (guerilla strategy). This presumably will happen in three steps (Fig. 6). The first step is the recovery of culm stature and the change in the composition of the shoot population in favour of PSH (and ISH), which happens within a few years (see Figs $4 \mathrm{c}$ and 5c). Presumably the next step is the increase in shoot density in surviving reed patches. We could show (see Fig. 3c) that this does not take place within the first two years, and, along with the retarded reed development after the extreme flood in 1965 (Ostendorp, 1990), we assume that a time lag of nearly a decade will be necessary. The final step would be the progression of the reed front into deeper water and into the fail areas. Presumably, this would last at least two or three decades, since we saw, reconstructing the reed development after the 1965 extreme flood, that till 1998 the reeds were not able to re-cover all the area they had covered before (Dienst, 1986; Ostendorp et al. 1996). Even under favourable conditions as in the early 1990s the progression did not exceed $0.4 \mathrm{~m} \mathrm{y}^{-1}$ (Schmieder et al., 2002).

It is assumed that the lesser affected reeds (i.e. damage classes G1 and G2) will follow the path of recovery outlined above, but the extremely damaged stands of the G5 class will finally die within a few years. This is indicated by the fact that the $\mathrm{rZ}$ values were significantly lower than zero (see Fig. 3c). The future development of moderately and strongly affected stands (G3 and G4) will be influenced by random factors which affect most or even all reed areas at Lake Constance shore, i.e. extreme floods whose probability may change during time, series of extreme low water periods like those in the 1990s (see Fig. 1), heavy storms (i.e. mechanical threat due to waves and drifting matter). On a more local scale, factors like wave exposure, elevation of the stand, sediment quality, management (e.g. winter harvesting), infestation by phytophageous arthropods (e.g. Donacia sp.) may act as additional stressors.

We hypothesize that in the long run, and on a lakewide scale, the frequency, magnitude and duration of extreme events are essential elements of the disturbance regime of Lake Constance reeds, and that the dynamics of the lakeside reed front is under the control of this disturbance regime which, however, may change during time.

\section{Acknowledgements}

This research project is funded by the BW-Plus programme of the State of Baden-Württemberg (No. BWC 20011). We are also grateful to the State Water Authorities in Rottweil and Ravensburg, and to the State Institute of Lake Research, Langenargen for their support.

\section{References}

Brändle, R., 1983. Evolution der Gärungskapazität in den flut- und anoxiatoleranten Rhizomen von Phalaris arundinacea, Phragmites communis, Schoenoplectus lacustris und Typha latifolia. Botanica Helvetica 93: 39-45.

Brändle, R., 1985. Kohlenhydratgehalt und Vitalität isolierter Rhizome von Phragmites australis, Schoenoplectus lacustris und Typha latifolia nach mehrwöchigem $\mathrm{O}_{2}$-Mangelstress. Flora 177: 317-321.

Brändle, R. \& R. M. M. Crawford, 1987. Rhizome anoxia tolerance and habitat specialization in wetland plants. In Crawford R. M. M. (ed.), Plant Life in Aquatic and Amphibious Habitats, pp. 397-410. Blackwell.

Brix, H., 1999. The European Research Project on Reed Die-back and Progression (EUREED). Limnologica 29: 5-10.

Conert, H. J., 1998. Phragmites. In Hegi, G. Illustrierte Flora von Mitteleuropa. Vol. I/3. 3rd ed. Parey Publ. Berlin: 126-133.

Dienst, M., 1986. Zur Dynamik der Schilffront am BodenseeUntersee. Natur und Landschaft 61: 137-139.

Hürlimann, H., 1951. Zur Lebensgeschichte des Schilfs an den Ufern der Schweizer Seen. Beitr. Geobot. Landesaufnahme Schweiz 30: 232 pp.

Ostendorp, W., 1989. 'Die-back' of reeds in Europe - A critical review of literature. Aquatic Botany Amsterdam 35: 5-26.

Ostendorp, W., 1990. Die Ursachen des Röhrichtrückgangs am Bodensee-Untersee. Carolinea 48: 85-102.

Ostendorp, W., 1993. Schilf als Lebensraum. Beih. Veröff. Naturschutz Landschaftspflege Baden-Württemberg 68: 173-280.

Ostendorp, W., H. Stark, P. Krumscheid-Plankert \& A. Pier, 1996. Dynamics and restoration of lakeside reedbelts in a prealpine lake (Lake Constance, Germany). Proceedings of Ecohydraulics, Quebec, June 1996: B753-B765.

Rodewald-Rudescu, L., 1974. Das Schilfrohr Phragmites communis Trin. Die Binnengewässer 27: 302 S.. Stuttgart.

Scheirer, C. J., W. S. Ray \& N. Hare, 1976. The analysis of ranked data derived from completely randomized factorial designs. Biometrics 32: 429-434.

Schmieder, K., M. Dienst \& W. Ostendorp, 2002. Auswirkungen des Extremhochwassers 1999 auf die Flächendynamik und Bestandsstruktur der Uferröhrichte des Bodensees. Limnologica 31: 131-146.

Studer, C. \& R. Brändle, 1984. Sauerstoffkonsum und-versorgung der Rhizome von Acorus calamus, Glyceria maxima, Menyanthes trifoliata, Phalaris arundinacea, Phragmites communis und Typha latifolia. Botanica Helvetica 94: 23-31. 
Urbanska, K. M., 1992. Populationsbiologie der Pflanzen: 374 pp, G. Fischer, Stuttgart.

Van der Putten, W. H., 1997. Die-back of Phragmites australis in European wetlands: an overview of the European Research programme on Reed Die-back and progression (1993-1994). Aquat. Bot. 59: 263-275.
White, P. S. \& A. Jentsch, 2001. The search for generality in studies of disturbance and ecosystems dynamics. Progress in Botany 62: 399-450.

White, P. S. \& S. T. A. Pickett (eds), 1985. The Ecology of Natural Disturbance and Patch Dynamics. Academic Press, New York. 